\title{
Pengaruh Model Pembelajaran Generatif Berbantuan Media Laboratorium Virtual Terhadap Penguasaan Konsep Fisika Siswa pada Materi Momentum dan Impuls
}

\author{
I Nyoman Sugiana ${ }^{1}$, Ahmad Harjono ${ }^{1}$, Hairunnisyah Sahidu ${ }^{1}$, Gunawan $^{1}$ \\ ${ }^{1}$ Program Studi Pendidikan Fisika \\ FKIP Universitas Mataram \\ Mataram, Indonesia \\ Email: nyomansugiana60@gmail.com
}

\begin{abstract}
This "non-equivalent control group design" quasi experimental research was purposed to identify the effect of generative-based learning model using virtual laboratory media towards the students' concept mastery and creativity in physics. The population of this research is all 173 students of $X$ grade in SMK Negeri 7 Mataram. The X grade students of Teknik Komputer Jaringan A (TKJ-A) department was determined as the experimental group and the X grade students of Teknik Komputer Jaringan B (TKJ-B) department was the control group. The way of collecting data for the concept mastery was done by using multiple choice test. The result revealed that the mean score of the post-test for the concept mastery was 43 for the experimental group with the highest score 56. Meanwhile the mean score of the control group was 36 with the highest score 52. The research hypothesis was tested using t-test pooled variances. The result showed that the value of $t_{\text {tab }}$ is higher than $t_{\text {arith }}$ the value is 3,42 >2,00 for the concept mastery. As the conclusion, this research showed that there was an effect towards the experimental group students' concept mastery and creativity in physics which was treated using generative-based learning model using virtual laboratory media.
\end{abstract}

Keywords: generative-based learning, virtual laboratory media, concept mastery

\section{Pendahuluan}

Pembelajaran adalah suatu proses yang dapat menimbulkan minat bagi seseoarang. Siswa selalu memiliki gaya pembelajaran yang berbeda-beda serta penilaian berbeda mengenai pembelajaran yang sedang berlangsung. Ilmu Pengetahuan Alam atau sains merupakan suatu cara mengetahui keteraturan alam secara sistematis untuk menguasai pengetahuan, fakta, konsep, prinsip, proses penemuan maupun suatu sikap ilmiah [1].

Fisika merupakan cabang dari IPA (sains), dimana pada hakikatnya merupakan kumpulan pengetahuan, cara penyelidikan, dan cara berpikir. Fisika merupakan salah satu mata pelajaran yang menimbulkan kesulitan kepada siswa, meskipun sudah didapatkan siswa sejak jenjang Sekolah Dasar (SD), meskipun masih tergabung dalam mata pelajaran Sains (IPA), dan terus berlanjut hingga ke jenjang Sekolah Menengah Atas (SMA).

Hal ini terjadi karena fisika dianggap sebagai mata pelajaran yang banyak memiliki persamaan dan kompleks, menyebabkan kemampuan siswa yang terbatas, dan kurangnya minat terhadap fisika. Untuk itu, pembelajaran IPA (fisika) yang harusnya disajikan dengan menggunakan model pembelajaran yang lebih bervariasi serta proses pembelajaran yang berpusat pada siswa (student centre) menjadikan siswa sebagai peserta didik yang aktif. Aktivitas dan kreativitas guru memiliki peranan penting terhadap aktivitas siswa dalam pembelajaran sehingga guru dapat menciptakan lingkungan belajar yang kondusif.

Dengan demikian, salah satu keterampilan yang harus dimiliki oleh guru dalam pembelajaran adalah keterampilan memilih model pembelajaran. Pemilihan model pembelajaran ini terkait langsung dengan usaha-usaha guru dalam menampilkan pengajaran yang sesuai dengan situasi dan kondisi, sehingga tujuan pembelajaran dapat tercapai dengan optimal. Pelaksanaan pengajaran dapat berjalan secara efisien dan efektif dengan menggunakan proses belajar mengajar yang lebih bermakna dan mengaktifkan siswa pada suatu skenario pembelajaran yang jelas.

Model pembelajaran merupakan disain yang menggambarkan suatu proses rincian kegiatan pembelajaran dan penciptaan situasi lingkungan secara sistematis yang memungkinkan siswa berinteraksi, sehingga terjadi perubahan atau perkembangan dalam diri siswa. Pemilihan suatu model pembelajaran yang tepat dalam proses pembelajaran fisika akan berpengaruh terhadap minat serta kemampuan siswa. Salah satu model pembelajaran yang didesain dimana siswa secara aktif berpartisipasi secara langsung dalam proses pembelajaran dan mengkonstruksi makna dari informasi pengetahuan awal dan pengalaman yang dimiliki siswa adalah model pembelajaran generatif [2].

Model pembelajaran generatif merupakan model pembelajaran yang membimbing siswa dalam mengeksplorasi pengetahuan siswa untuk memperoleh pengetahuan baru. Wena membagi model pembelajaran generatif menjadi empat tahap, yaitu (a) pendahuluan (persiapan), (b) pemfokusan, (c) tantangan (pengenalan konsep), dan (d) Aplikasi [2]. Selain penggunaan model, media pembelajaran 
memiliki peranan penting dalam keberhasilan pembelajaran.

Media pembelajaran yang menguntungkan yaitu media yang menggunakan teknologi dalam mengakses informasi yang diperlukan siswa baik dari guru, teman sebaya dan aplikasi perangkat [3]. Penelitian ini menggunakan media laboratorium virtual karena tidak adanya kegiatan eksperimen pada materi momentum dan impuls. Media laboratorium virtual adalah suatu media berbasis komputer berupa simulasi kegiatan laboratorium seperti halnya kegiatan eksperimen di laboratorium sebenarnya.

Belum adanya penggunaan model pembelajaran generatif yang digabungkan dengan media laboratorium virtual, serta beberapa penelitian terkait masih pada mata pelajaran bahasa, matematika dan kimia. Peneliti merasa tertarik untuk melakukan penelitian pada bidang studi fisika. Penggunaan model pembelajaran generatif yang digabungkan dengan media laboratorium virtual merupakan pada salah satu sekolah yang pengadaan alat-alat laboratoriumnya belum memadai dari segi kuantitas yaitu di SMK Negeri 7 Mataram sangat cocok. Hasil observasi pada sekolah sangat mendukung, dimana menunjukan bahwa keberadaan laboratorium, baik ruangan laboratorium yang diubah menjadi kelas untuk belajar maupun alat-alat eksperimen yang digunakan belum lengkap. Penelitian bertujuan untuk mengetahui pengaruh model pembelajaran generatif berbantuan media laboratorium virtual mampu meningkatkan penguasaan konsep pada pembelajaran fisika di tingkat sekolah menengah kejuruan.

\section{TINJAUAN PUSTAKA}

\section{A. Pembelajaran Generatif}

Penentuan model pembelajaran yang tepat bagi siswa dapat menentukan keberhasilan dalam suatu proses pembelajaran. Salah satu model pembelajaran yang dapat digunakan sesuai dengan kemampuan siswa. Pembelajaran generatif pertama kali dipubikasikan oleh Osborne dan Cosgrove. Pembelajaran generatif merupakan variasi metode yang dapat menyelidiki pemahaman siswa serta menemukan maksud siswa dalam menyelesaikan permasalahan kehidupan sehari-hari.

Wena membagi model pembelajaran generatif menjadi empat tahap, yaitu (a) pendahuluan (persiapan), (b) pemfokusan, (c) tantangan (pengenalan konsep), dan (d) Aplikasi [2]. Hal ini sejalan dengan pendapat Erlendsson yang menyatakan bahwa dalam pelaksanaan model pembelajaran generatif terdapat 4 strategi yang dapat dilakukan yaitu Recall, Integration, Organization, and Elaboration [4].

Dari pemaparan beberapa pendapat yang telah diuraikan, dapat disimpulkan bahwa model pembelajaran generatif adalah model pembelajaran yang berbasis paham konstruktivisme yang lebih menekankan pengintegrasian pengetahuan baru dengan pengetahuan yang dimiliki siswa sebelumnya, dengan sintaks yang digunakan adalah persiapan, pemfokusan, tantangan, dan aplikasi.

\section{B. Media Laboratorium Virtual}

Siswa dapat mengembangkan kemampuan dalam mengoperasikan komputer dan sudah mengenal pentingnya pendidikan yang menjadi masalah dalam suatu proses pemecahan masalah di kehidupan seharihari [5]. Penggunaan model pembelajaran, masih belum dapat dilakukan secara optimal sebagai suatu tindakan yang dapat mengubah minat siswa, dengan adanya media pembelajaran siswa merasa lebih tertarik dalam belajar.

Salah satu penggunaan media yang cocok untuk pembelajaran fisika adalah media laboratorium virtual. Laboratorium virtual adalah laboratorium yang digunakan siswa dalam melakukan eksperimen tanpa memerlukan adanya alat-alat laboratorium riil. Gunawan [1] menyatakan bahwa laboratorium virtual dapat didefinisikan sebagai suatu bentuk objek multimedia yang interaktif.

Peneliti menyimpulkan bahwa media laboratorium virtual adalah suatu media berbasis komputer berupa simulasi kegiatan laboratorium seperti halnya kegiatan eksperimen di laboratorium sebenarnya.

\section{Penguasaan Konsep}

Belajar konsep merupakan hasil utama pendidikan. Konsep-konsep merupakan suatu landasan dalam berpikir dan menemukan suatu pemecahanmasalah. "Konsep-konsep merupakan dasar bagi proses-proses mental yang lebih tinggi untuk merumuskan prinsipprinsip dan generalisasi-generalisasi untuk memecahkan masalah, seorang siswa harus mengetahui aturan-aturan yang relevan, dan aturanaturan ini didasarkan pada konsep-konsep yang diperolehnya" [6]. Menurut Ausubel [7] konsepkonsep diperoleh melalui dua cara, yaitu formasi konsep dan asimilasi konsep. Konsep dapat diartikan sebagai buah pemikiran seseorang atau kelompok orang yang dinyatakan dalam definisi sehingga melahirkan produk pengetahuan meliputi prinsip, hukum, dan teori. Konsep dapat menunjukkan hubungan suatu konsep dengan konsep lain yang lebih sederhana sebagai dasar perkiraan atau jawaban. Konsep diperoleh dari fakta, peristiwa, pengalaman melalui generalisasi dan berpikir abstrak, kegunaan konsep untuk menjelaskan dan meramalkan.

Penguasaan konsep fisika merupakan salah satu aspek dalam mengukur hasil belajar siswa yang didapat guna mewujudkan pembelajaran. Penguasaan konsep pada penelitian ini menggunakan tes pilihan ganda sebanyak 30 soal. Untuk indikator penguasaan konsep menggunakan ranah kognitif pada aspek $\mathrm{C} 1$ sampai C6 yaitu dari C1 (memahami), C2 (aplikasi), C3 (analisis), C4 (sintesis), C5 (Evaluasi), dan C6 (mencipta). Dari kemampuan penguasaan konsep 
fisika siswa, dapat menumbuhkan sikap kreatif dalam memecahkan masalah fisika. Dari uraian di atas peneliti mendefinisikan penguasaan konsep adalah suatu kemampuan kognitif siswa pada materi impuls dan momentum yang dapat diukur melalui ranah $\mathrm{C} 1$ sampai C6 (memahami sampai mencipta) sesuai dengan taksonomi Bloom.

\section{Metode penelitian}

Penelitian ini merupakan penelitian kuasi eksperimen dengan menggunakan desain penelitian yaitu "non-equivalent control group design". Proses pembelajaran menggunakan model pembelajaran generatif yang dipadukan media laboratorium virtual pada kelas eksperimen dan model pembelajaran langsung pada kelas kontrol. Instrumen penguasaan konsep menggunakan tes pilihan ganda, dengan subjek penelitian ini adalah siswa kelas X TKJ di SMKN 7 Mataram Tahun Ajaran 2015/2016.

Data hasil penguasaan konsep di uji prasyarat analisis berupa uji homogenitas menggunakan uji-F dan uji normalitas menggunakan uji Chi Kuadrat. Kemudian dilanjutkan dengan uji hipotesis menggunakan uji-t polled varian. Sedangkan untuk mengetahui peningkatan per sub materi menggunakan uji $n$-gain.

\section{HASIL DAN PEMBAHASAN}

Penelitian yang sudah dilakukan kurang lebih dua bulan. Penelitian penguasaan konsep ini mengukur ranah kognitif dari $\mathrm{C} 1$ sampai $\mathrm{C} 6$ untuk tes penguasaan konsep yang bertujuan untuk mengetahui pengaruh pembelajaran fisika menggunakan model pembelajaran generatif berbantuan media laboratorium virtual terhadap penguasaan konsep siswa. Data tentang hasil kemampuan siswa sebelum dan sesudah perlakuan diperoleh melalui tes awal dan tes akhir.

Kemampuan awal penguasaan konsep siswa baik kelas eksperimen maupun kelas kontrol berdasarkan hasil tes awal masih rendah. Hal ini terlihat dari nilai rata-rata tes penguasaan konsep masing-masing kelas, yaitu untuk kelas eksperimen 25 dan untuk kelas kontrol 24, rata-rata tersebut dikategorikan tidak tuntas. Hal ini disebabkan karena kurangnya kemampuan awal siswa untuk menghubungkan pengetahuan yang lama dengan pengetahuan baru dan bagaimana mengkonstrusikan pengetahuan tersebut, sehingga solusi yang diterapkan oleh peneliti adalah melaksanakan pembelajaran menggunakan model generatif dengan berbantuan media laboratorium virtual.

Pengambilan data untuk kemampuan awal berupa tes obyektif dengan bentuk tes pilihan ganda sebanyak 25 soal. Sebelum mendapatkan 25 soal, Uji validitas soal dilakukan sebanyak dua kali pada kelas XI TKJA dan XI TKJB dengan membuat 30 soal. Pada hasil uji coba instrumen pertama terdapat 16 soal yang diterima, 12 soal yang direvisi dan 2 soal dibuang. Berdasarkan hasil uji validitas tersebut, terdapat 14 soal yang tidak valid. Dari 14 soal yang tidak valid 12 soal yang direvisi berdasarkan pertimbanganpertimbangan uji analisis soal lainnya, seperti uji indeks kesukaran, daya beda, dan uji reliabelitas. Adapun soal yang direvisi adalah 14 soal yang kemudian di uji kembali di kelas yang berbeda. Pada hasil uji coba instrumen kedua terdapat 7 soal yang diterima, 2 soal yang direvisi dan 5 soal dibuang. Sehingga dapat disimpulkan 23 soal yang diterima, 2 soal yang direvisi dan 5 soal dibuang. Peneliti menyimpulkan untuk mengambil 25 soal untuk digunakan pada saat melakukan tes awal dan tes akhir.

Hasil penelitian yang sudah dilakukan menggambarkan bahwa kemampuan akhir penguasaan konsep berbeda dengan kemampuan awalnya. Kelas eksperimen maupun kelas kontrol mengalami peningkatan, namun peningkatan kelas eksperimen lebih baik daripada peningkatan pada kelas kontrol. Hal ini disebabkan karena pada kelas eksperimen menggunakan model pembelajaran generatif berbantuan media laboratorium virtual. Kegiatan pembelajaran di kelas eksperimen (menggunakan model pembelajaran generatif) berbeda dengan peningkatan kemampuan penguasaan konsep pada kelas kontrol. Pembelajaran generatif memiliki empat tahapan, yaitu persiapan, pemfokusan, tantangan dan aplikasi yang terlihat dalam kegiatan guru dan siswa. Berdasarkan analisis hasil tes akhir yang telah dilakukan, untuk penguasaan konsep didapatkan nilai rata-rata kelas eksperimen sebesar 43 dengan nilai tertinggi 56, sedangkan nilai rata-rata kelas kontrol sebesar 36 dengan nilai tertinggi 52. Sebelum melakukan uji-t pada hasil kemampuan awal dan kemampuan akhir, dilakukan terlebih dahulu uji normalitas dan uji homogenitas. Uji ini dilakukan bertujuan utuk memperoleh sampel yang berdistribusi normal, yaitu untuk uji normalitas dan uji homogenitas bertujuan untuk mengetahui apakah varians kelas eksperimen dan kelas kontrol sama. Persentase peningkatan penguasaan konsep fisika siswa pada kelas eksperimen dan kontrol disajikan pada Gambar 1.

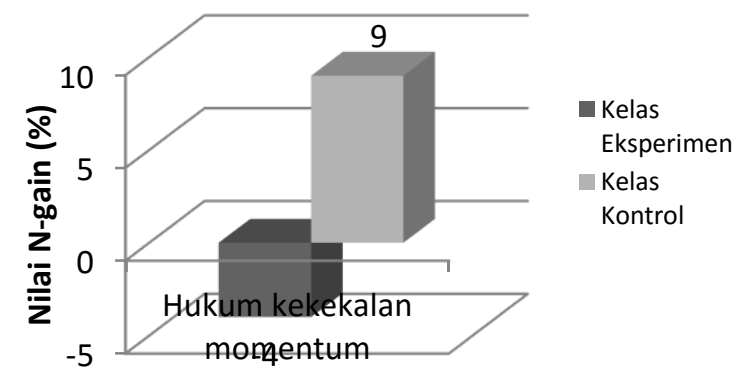

Gambar 1. Komposisi N-gain Sub-Materi Hukum Kekekalan Momentum

Hasil uji N-gain yang dilakukan pada materi hukum kekekalan momentum di kelas eksperimen 
mengalami penurunan persentase sebanyak $4 \%$. Hal ini dikarenakan kategori beberapa soal dengan kategori sukar dengan daya beda yang cukup dan jelek. Kemampuan siswa yang memerlukan latihan soal juga menjadi masalah dalam mengajarkan tingkat materi yang cukup dalam.

Setelah dilakukan uji hipotesis dengan menggunakan uji statistik (uji-t polled varian), diperoleh nilai thitung lebih besar dari ttabel yaitu $3,42>2,00$. Hal ini berarti terdapat pengaruh penguasaan konsep fisika siswa antara kelas eksperimen yang diberikan perlakuan berupa penerapan model pembelajaran generatif berbantuan media laboratorium virtual dengan kelas kontrol yang diberikan perlakuan berupa penerapan model pembelajaran langsung tanpa bantuan media laboratorium virtual. Penguasaan konsep merupakan bagian dari peningkatan hasil belajar. Temuan dalam penelitian ini memperkuat beberapa penelitian sebelumnya diantaranya penelitian yang dilakukan Tan [8] menyatakan bahwa kemampuan kognitif dan pedagogik memiliki hubungan antara pembelajaran generatif dan berpikir tingkat tinggi yang dapat ditinjau secara singkat. Serta dalam penelitian lain guru ingin memulai menggunakan pembelajaran berbasis komputer dan belajar pada pembelajaran kimia membutuhkan partisipasi guru dan membutuhkan pelatihan aplikasi komputer yang khusus [9]. Ulusoy \& Onen [10] menyatakan bahwa aktivitas pembelajaran berbasis konteks menggunakan model pembelajaran generatif menimbulkan motivasi siswa pada pembelajaran kimia bertambah baik dan sikap praktik kimia meningkat kearah yang baik berdasarkan tingkatan tes yang diberikan. Penelitian Juani [11] menyatakan bahwa kemampuan penalaran matematika siswa kelas XI SMK yang belajar dengan model pembelajaran generatif lebih tinggi daripada siswa yang diajar dengan model pembelajaran matematika knisley. Hasil penelitian tersebut membuktikan penggunaan model pembelajaran generatif dan media laboratorium virtual dalam pembelajaran langsung berpengaruh positif terhadap penguasaan konsep fisika siswa.

\section{PENUTUP}

Berdasarkan uji hipotesis, dapat disimpulkan bahwa terdapat pengaruh penguasaan konsep fisika siswa antara kelas eksperimen yang diberikan perlakuan berupa penggunaan model pembelajaran generatif berbantuan media laboratorium virtual. Tetapi pembelajaran langsung pada kelas kontrol lebih baik dalam materi hukum kekekalan momentum hal ini dikarenakan sub-materi hukum kekekalan momentum mengalami peningkatan pada kelas kontrol. Hal ini dikarenakan pada materi tersebut ranah kognitif memiliki aspek berpikir tingkat sedang sampai tinggi yaitu dari C3 sampai C6. Pada aspek tersebut memerlukan latihan soal yang runtut sehingga model pembelajaran langsung lebih tepat dalam materi tersebut.

Adapun saran yang dapat diberikan peneliti selanjutnya yaitu, penggunaan model pembelajaran generatif pada sub materi dengan ranah kognitif C3 sampai C6 memerlukan banyak latihan soal, sehingga tahapan pembelajaran aplikasi harus dioptimalkan. Mengenai penggunaan media laboratorium virtual harus disesuaikan dengan indikator penguasaan konsep. LK (Lembar Kerja) untuk media laboratorium virtual yang diberikan dapat diisi dengan beberapa soal beserta langkah-langkah pengerjaaannya. Soal pada ranah kognitif C3 sampai C6 dibuat lebih sederhana agar siswa lebih mudah dalam memahami soal.

\section{UCAPAN TERIMA KASIH}

Terima kasih disampaikan kepada Tim Hibah Penelitian Strategis Nasional Kemenristek Dikti Tahun 2016 yang telah melibatkan kami dalam penelitiannya, membimbing dan mengajarkan banyak hal, serta memfasilitasi semua proses hingga publikasi ilmiah bersama. Terima kasih juga disampaikan kepada Bapak Kepala SMKN 7 Mataram serta guru dan staf dilingkungan sekolah yang membantu dalam kegiatan penelitian ini.

\section{REFERENSI}

[1] Gunawan. 2015. Model Pembelajaran Sains Berbasis ICT. Mataram: FKIP UNRAM.

[2] Wena, M. 2014. Strategi Pembelajaran Inovatif Kontemporer. Jakarta: Bumi Aksara.

[3] Fabian, K., Topping, K. J., Barron, I. G., and Chuah, K.' M. 2016. Mobile Technology and Mathematics: Effects on Students' Attitudes, Engagement, and Achievement. J. Comput. Educ. 3(1): 77-104.

[4] Lusiana., Hartono, Y., dan Saleh, T. 2009. Penerapan Model Pembelajaran Generatif (Mpg) untuk Pelajaran Matematika di Kelas X SMAN 8 Palembang. Jurnal Pendidikan Matematika. 3 (2): 30-31.

[5] Ying, H.W., Huang, I., \& Jen, G.H.. 2016. Comparison of the effects of project-based computer programming activities between mathematics-gifted students and average students. J. Compt. Edu. 3(1): 33-45.

[6] Dahar, R.W. 1996. Teori-teori Belajar. Bandung: Erlangga.

[7] Ausubel, D.P., Novak, J.D., and Hanesian, H. 1978. Educational Psychology: A Cognitive View (2 nd.ed). New York: Holt, Rinehart and Winston.

[8] Tan, W.C., Aris, B., and Abu, S. 2006. GLOTT Model: A pedagogically-enriched design framwork of learning environment to improve higher order thinking skills. AACE Journal, 14(2): 139-153.

[9] Pietzner, V. 2014. Computer-Based Learning in Chemistry Classes. Eurasia Journal of Mathematics, Science \& Technology Education. 10(4): 297-311. 
[10] Ulusoy, F. M., and Onen, A. S. 2014. A Research on the Generative Learning Model Supported by Context-Based Learning. Eurasia Journal of Mathematics, Science \& Technology Education. 10(6): 537-546.

[11] Juani, A., Salsabila, E., dan Irawan, B. 2014. Perbandingan Kemampuan Penalaran Matematika antara Siswa yang diajar Menggunakan Model Pembelajaran Generatif dan Model Pembelajaran Matematika Knisley (Mpmk) Pada SMKN 26 Jakarta. JMAP. 13 (1): 48.

\section{Biografi Penulis}

I Nyoman Sugiana, lahir di Gilimanuk 11 Juni 1994. Tahun 2012 lulus di SMAN 1 Melaya dan melanjutkan pendidikan S-1 di Universitas Mataram pada program studi pendidikan fisika hingga meraih gelar sarjana pendidikan pada tahun 2016. 